\title{
Determination of Electrochemical Generator Power in Combined Transport Power Plant
}

\author{
Kirill I. Kulikov, Nikolai I. Schurov, Mikhail V. Yaroslavtsev, Evelina G. Langeman \\ Department of Electrotechnical Complexes \\ Novosibirsk State Technical University \\ Novosibirsk, Russia \\ kirill_kulikov1993@mail.ru
}

\begin{abstract}
The increase in passenger flow and the transport speed requires a correspondence of designed vehicles to the high requirements of environmental and transport safety as well as energy efficiency. The compliance of vehicles to high quality standards encourages world manufacturers to develop new types of traction drives with electric traction. In this regard, it seems promising enough to study and develop a hydrogen-fueled power plant, which will make a smooth transition from the use of internal combustion engines to vehicles with the technological principles. Described study is based on experimental data of the on-board recorder installed on trolleys and obtained information about the rolling stock motion pattern. The obtained data allows calculating a power, which must be output by a planned traction drive. To ensure the required running transport qualities, with a low conversion dynamics of hydrogen given, the various energy storage devices in combination with fuel cells are discussed. The power value which could be provide due to a chemical reaction of hydrogen conversion is defined. The further research direction is also mentioned.
\end{abstract}

Keywords-public transport; fuel cell; combined power plant.

\section{INTRODUCTION}

The modern sector of the autonomous electrical transport is going through an era of intensive development. By 2035, as shown in a study conducted by the National Association of oil and gas service of Russian Federation, electric cars will take no less than $50 \%$ of car market [6]. Research in the field of combustion in internal combustion engines (ICE) optimization has not stopped, and their potential continues to grow. The same can be said about the development of transport with hybrid power plants [9].

The autonomous electric transport as one of the modernity trends, which promote new research in the field of power sources, electric motors, systems of technical vision and, accordingly, reduces the unit production cost.

All of these factors, coupled with modern trends of widespread introduction of energy saving technologies encourage the world's carmakers pass on design of new vehicles types on the new technological principles.

At the moment, there is transition from fossil fuels to more environmental friendly traction electric drive (TED) in the segment of vehicles. The intensity of this transient phase directly depends on the affordability and technical characteristics of power sources, which put in motion electric vehicle. As on board drives automakers prefer to use traction batteries (TB) and capacitor batteries (CB) [2, 3]. Numerous studies of these two power sources combinations are carried on $[4,5]$.

However, there are a number of factors limiting the electric vehicles wide spreading with marked above energy storages, namely the limited radius of autonomous status and lack of charging stations.

Solution to this problem is the usage of on-board electric energy generator - fuel cell (FC), by analogy with the ICE, which carries out the conversion of the input fuel. However, unlike the ICE, whose work is characterized by intermediate transition stage, FC is characterized by direct conversion of fuels into electrical energy by "hydrogen->burning$>$ electricity ". In addition, related transport infrastructures in the form of petrol gas accumulating stations are already exist, and its adaptation for use of hydrogen/ hydrogenous containing fuel and it does not require substantial investments [8].

There are different types of FC. They are usually classified according to the fuel, working pressure and temperature, which determines the scope, efficiency, fuel type and type of catalyst used in FC. Currently, there are several types of FC, which have different composition of the used electrolyte:

- Proton Exchange Membrane Fuel Cells (PEMFC);

- Solid Oxide Fuel Cells (SOFC);

- Phosphoric Acid Fuel Cells (PAFC);

- Molten Carbonate Fuel Cells (MCFC);

- Fuel Cells Alkaline (AFC) [1].

In relation to power systems based on $\mathrm{FC}$ in transportation applications, there are a number of specific requirements. Such technical solutions must have competitive specific power $\left(0.5 \ldots 1 \mathrm{~mW} / \mathrm{sm}^{2}\right)$ and, consequently, acceptable general dimensions indicators, wide range of working temperatures, tolerant attitude to fuel, resistance to vibration load. These requirements correspond more closely to the fuel cells with proton exchange membrane (PEMFC) and solid oxide fuel cells (SOFC). Its' characteristics are shown in Table I [3]. 
TABLE I Fuel Cells' Characteristics

\begin{tabular}{|l|l|l|}
\hline \multirow{2}{*}{ Parameter } & \multicolumn{2}{|l|}{ Type of FC } \\
\cline { 2 - 3 } & PEMFC & SOFC \\
\hline Temperature, ${ }^{\circ} \mathrm{C}$ & $70 \ldots 90$ & $1073 \ldots 1273$ \\
\hline Used fuel & technical hydrogen & synthesis gas, methane \\
\hline Cathode material & carbon + platinum & $\begin{array}{l}\text { lanthanum, strontium, } \\
\text { manganese oxides }\end{array}$ \\
\hline Anode material & carbon/platinum & nickel/strontium oxides \\
\hline $\begin{array}{l}\text { Current density, } \\
\mathrm{kA} / \mathrm{m}^{2}\end{array}$ & $3 \ldots 5$ & $2 \ldots 4$ \\
\hline Life span, h & 20000 & 60000 \\
\hline Voltage, $\mathrm{V}$ & $0.75 \ldots 0.8$ & \\
\hline
\end{tabular}

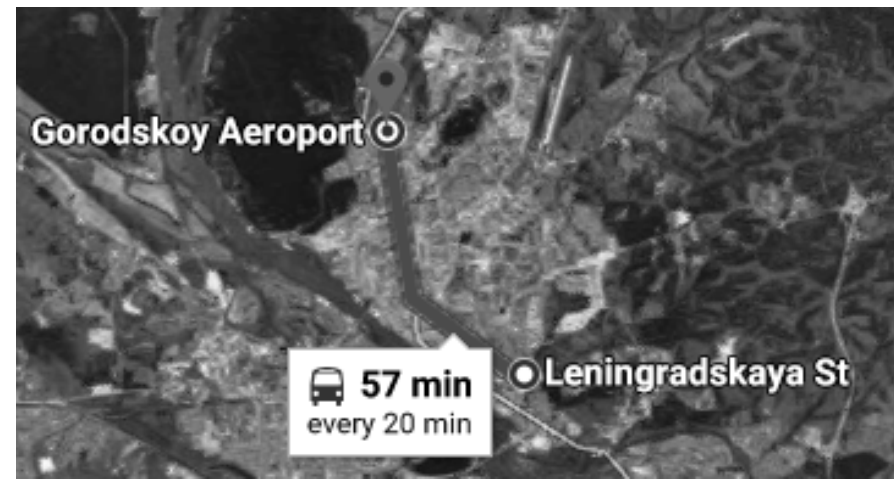

Fig.1. The movement scheme of investigated trolleybus.

The data used for analysis of mathematical model [9], in accordance with which calculations are made in the following sequence.

A determination of vehicle movement resistance $w_{i}$ by the values of the instantaneous velocity (1).

$$
w_{i}=16+0.004 V_{i}^{2}, \mathrm{~N} / \mathrm{kN}
$$

where $V_{i}$ - the speed value in the $i$-th time, $\mathrm{m} / \mathrm{s}$.

Calculation of the acceleration $a_{i}$ by values of instantaneous velocity (2):

$$
a_{i}=\frac{V_{i}-V_{i-1}}{\Delta t}, \mathrm{~m} / \mathrm{s}^{2},
$$

where $\Delta t$ - calculation step time is equal to $0.5 \mathrm{sec}$ to ensure the analysis accuracy.

Calculation values of traction and braking forces $F_{i}$ of traction drive (3), on the basis of the obtained values of time. The full weight of trolley bus (i.e. mass with permissible passenger capacity 108 people) is taken into account.

$$
F_{i}=(1+\gamma) m a_{i}+m g w, \mathrm{~N}
$$

where $\gamma$ - the coefficient that takes into account the inertia of the rotating parts;

$$
g \text { - free fall acceleration, } \mathrm{m} / \mathrm{s}^{2} \text {; }
$$

The evaluation of power consumed or returned by the traction drive during traction and braking modes, by means of one of the two expressions (4), (5):

$$
\begin{gathered}
P_{i}=\frac{F_{i} V_{i}}{\eta_{t}}, \mathrm{~W} ; \\
P_{i}=F_{i} V_{i} \eta_{r}, \mathrm{~W},
\end{gathered}
$$

where $\eta_{t}$ - traction drive efficiency during the traction, $a(t)>0$;

$\eta_{r}$ - traction drive efficiency during the recuperation mode, $a(t)<0$.

Numerical values of data used in calculation are presented in Table II. 
TABLE II Calculation Data

\begin{tabular}{|l|l|l|l|}
\hline Parameter & $\begin{array}{l}\text { Conventional } \\
\text { Value }\end{array}$ & Unit Amount & Value \\
\hline Trolleybus ZiU-682c & \multicolumn{4}{|l|}{} \\
\hline Vehicle capacity & - & $\begin{array}{l}\text { Passenger } \\
\text { number }\end{array}$ & 108 \\
\hline Full weight & $m_{f u l l}$ & $\mathrm{~kg}$ & 18306 \\
\hline Maximum speed & $V_{\max }$ & $\mathrm{km} / \mathrm{h}$ & 60 \\
\hline $\begin{array}{l}\text { Coefficient of rotating } \\
\text { parts inertia }\end{array}$ & $\gamma$ & - & 0.17 \\
\hline Free fall acceleration & $g$ & $\mathrm{~m} / \mathrm{s}^{2}$ & 9.81 \\
\hline Efficiency & $\eta$ & - & 0.35 \\
\hline
\end{tabular}

\section{EXPERIMENTAL DATA ANALYSIS}

Data analysis of on-board recorder showed that the speed of the trolley has been changed in the range from 0 to $14 \mathrm{~m} / \mathrm{s}$, which corresponds to $51 \mathrm{~km} / \mathrm{h}$ (Fig. 2).

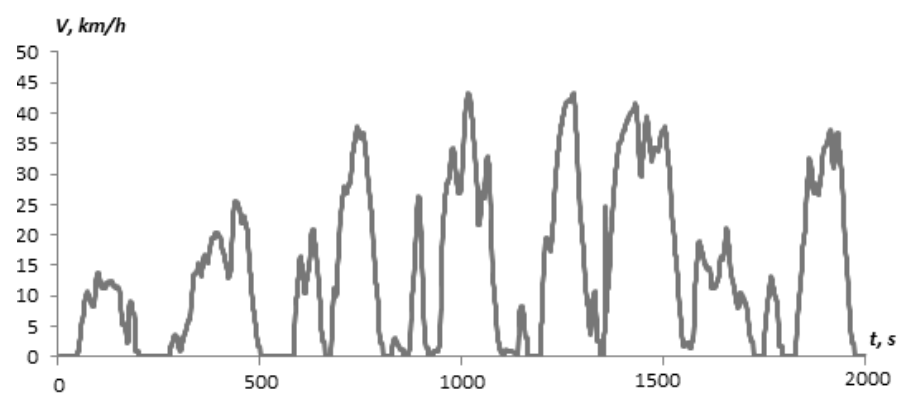

Fig. 2. The speed dependence from time.

The transport unit movement has been accompanied by an acceleration showed in Fig. 3. It shows that there were some zones in the path where acceleration developed in several times greater than allowed. This is a wheel slippage on ice.

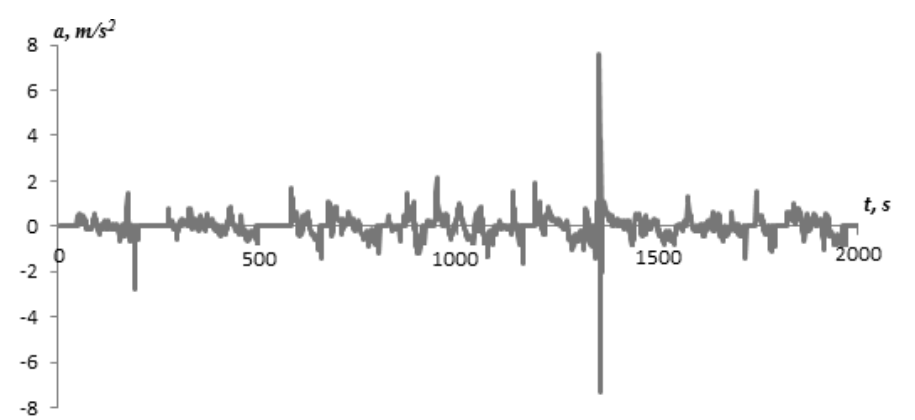

Fig. 3. The acceleration dependence from time.

Traction forces produced by TD during periods of acceleration and deceleration are shown in Fig. 4.

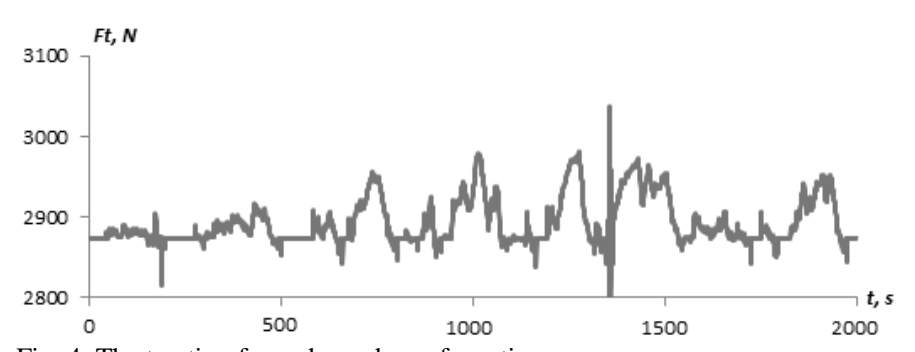

Fig. 4. The traction force dependence from time.
While calculating the power consumed during traction and generated during braking modes (Fig. 5), the efficiency of traction drive elements, which are fuel cell battery, traction converter, traction engine and mechanical transmission were taken into account.

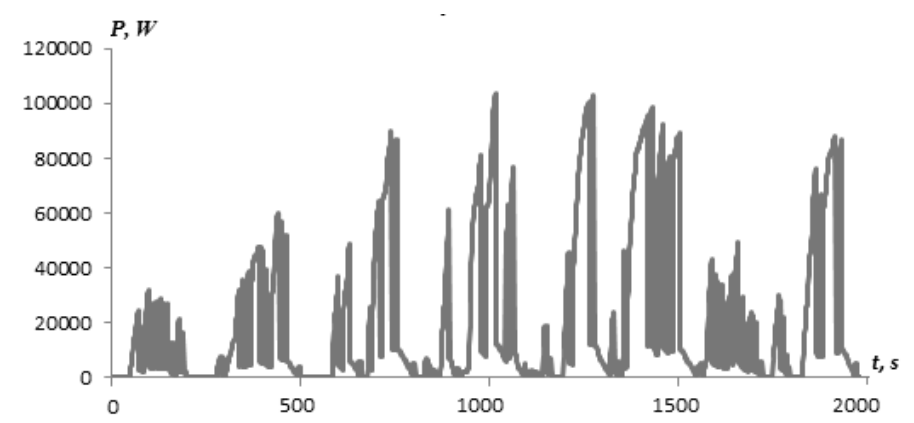

Fig. 5. The power dependence from time.

\section{RESULTS}

The specifications of electric power plant based on fuel cell should be taken into consideration in design. A typical fuel cell has a low dynamics and starting voltage in relation with a stable state, which is reached within a few tens of seconds after start. Therefore, the fuel cell is not able to supply drives with variable loading, which characterize transport, as the only source of supply. Some of fuel cells' characteristics are presented below in Fig. 6 and Fig. 7 [10].

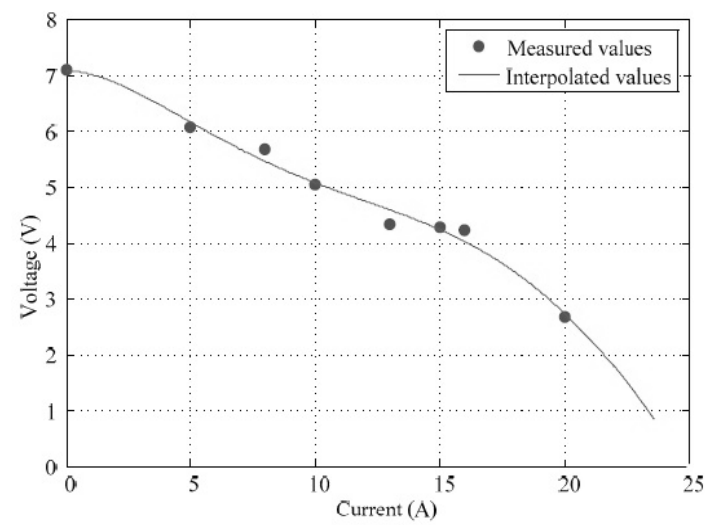

Fig. 6. Current-voltage characteristics of fuel cells.

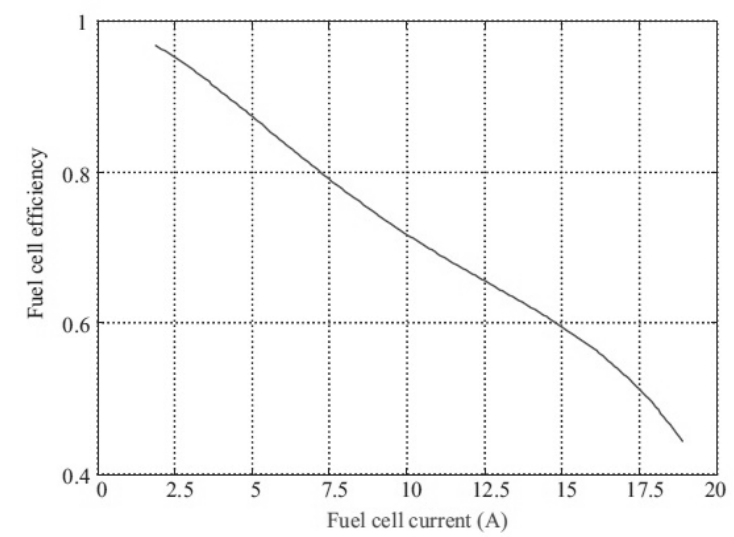

Fig. 7. Fuel cell efficiency. 
The fuel cell is capable of providing a stable electric power range [10] that justifies the prospect of combined power plants development, where a major source of supply is a fuel cell battery, and the functions of secondary energy storage include traction drive supply during periods of accelerations and receiving recovery energy during braking.

Based on recorder data processing, it was determined that the average power required for transport unit movement lies within $24 \mathrm{~kW}$. This level of load will be provided by fuel cells, and frequent, but short-lived acceleration, which periodically require power of $100 \mathrm{~kW}$ or more, will be provided by additional energy storage.

\section{OVERVIEW OF EXISTING SOLUTIONS}

The subject relevance is confirmed by the fact that the Belgian manufacturer Van Hool buses [12] received the order for the production and supply to the beginning of the 2019 year forty buses on hydrogen vehicles in Germany. This is the largest order for this type buses in Europe.

Buses of Van Hool A330 model with a length of 12 meters is a hybrid vehicles equipped with fuel cell type FCveloCity® manufactured by Ballard Power Systems [11] capable to supply $30-200 \mathrm{~kW}$ of power in relation to transport needs. In addition to the fuel cell, this model is also equipped with lithium-ion batteries of $30 \mathrm{kw}$ fuel cell module are presented in Table III.

\begin{tabular}{|l|l|l|}
\multicolumn{2}{|c|}{ TABLE III Technical Characteristics of Fuel Cell Batteries } \\
\hline Parameter & Unit Amount & Value \\
\hline Fuel cell type & - & $\begin{array}{l}\text { proton exchange } \\
\text { membrane }\end{array}$ \\
\hline Performance & $\mathrm{kW}$ & 30 \\
\hline $\begin{array}{l}\text { Operation voltage } \\
\text { range }\end{array}$ & $\mathrm{V}$ & $85-180$ \\
\hline Current & $\mathrm{A}$ & $0-300$ \\
\hline Dimensions & $\mathrm{mm}$ & $900 \times 480 \times 375$ \\
\hline Weight & $\mathrm{kg}$ & 125 \\
\hline Fuel type & & Gaseous hydrogen \\
\hline Oxidizer & & air \\
\hline Cooling type & & $50 \%$ ethylene glycol, \\
& & $50 \%$ deionized water \\
\hline Fuel pressure & bar & 8 \\
\hline Fuel feed rate & $\mathrm{g} / \mathrm{s}$ & 0.7 \\
\hline Fuel feed rate & $\mathrm{dB}$ & $<75$ \\
\hline
\end{tabular}

Such hybrid arrangement application allows the bus works all day after one fuel charge. Hydrogen tank capacity in 38.2 $\mathrm{kg}$ is enough to cover a distance of $350 \mathrm{~km}$. Batteries serve as a backup power source, giving out energy when it is needed. Coupled with recuperation of braking energy bus requires $8 \mathrm{~kg}$ of hydrogen to overcome $100 \mathrm{~km}$. The traction drive arrangement of the reporting Van Hool A330 is shown in Fig. 8.

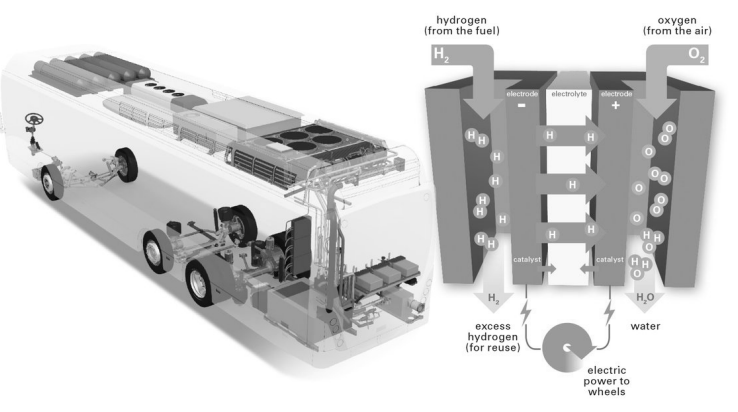

Fig. 8. The arrangement of the hydrogen bus.

\section{CONCLUSION}

Due to the availability of the necessary infrastructure, environmental safety of hydrogen and high energy efficiency of traction drive on its basis researches in this direction should be continued. Conducted experiment is the starting point for the design of combined power plant based on fuel cells. Further work will be devoted to the modelling work of the traction drive with two energy sources, one of which is the fuel cell battery.

The decision of an additional energy source is not made, because the applications range of hydrogen fuel vehicles is wide - urban transport, intercity transportation, personal vehicles. It is possible that for different traffic conditions can be justified the usage of ultracapacitors and accumulators.

\section{References}

[1] F. I. Abramchuk and A. P. Kuz'menko, "Choice and justification of the fuel element for ekomobile," Road transport (Kharkiv) vol.№33, 2013, pp. 50-54.

[2] K.I. Kulikov and N.I. Schurov, "Autonomous electric transport trends and development prospects," Scientific problems of transport of Siberia and the Far East, vol.№3-4, 2017, pp. 216-220,

[3] K.I. Kulikov, N.I. Schurov and E.G. Langeman, "Structural analysis of vehicle's hybrid power system based on fuel cell," Collection of proceedings of the XIX international conference of young specialists on micro / nanotechnologies and electronic devices, in press.

[4] S.V.Popov and M.U. Gurtovyi. "Development of an electric vehicle mathematical model with combined power sources," East-European journal of advanced technologies, vol.№8. 2015, pp. 4-8.

[5] P.I. Rozkaryaka and D.N. Miroshnik, "Modeling of the hybrid source control system "battery - supercapacitor", Zavalishin's reading, 2016. pp. 206-211.

[6] S.B. Sobolevskij, "Prospects for the use of alternative fuels and the development of electric transport," Prospects for the development of the transport complex, 2016, pp. 14-22.

[7] A.I Sorokin and G.K. Mirzoev, "Alternative fuels using efficiency in the internal combustion engines," Chemistry for sustainable development, vol.№6, 2005, pp. 805-808.

[8] O.V.Shugaev and T.V Voskresenskaia, "The rationale for the choice and argumentation using hydrogen fuel cell car," Journal of Siberian State Industrial University, vol.№3, 2016, pp. 19-22

[9] M.V. Yaroslavtsev, N.I Schurov., V.N Anosov, "Energy efficient traction drive of urban road transport," Novosibirsk: Publ. NSTU, 2017, 136 p.

[10]F. Ciancetta, A. Ometto, A. Rotondale, G.D'Ovidio, C.Masciovecchio, "Energy storage system comparison for mini electrical bus," Power Electronics, Electrical Drives, Automation and Motion (SPEEDAM), 2016, pp. 1115-1119.

[11]Putting fuel cells to work [Online]. Available: http://www.ballard.com/fuel-cell-solutions/fuel-cell-power-products

[12] The road is ahead [Online]. Available: https://www.vanhool.be/en/ 